\title{
THE HAPPINESS AND THE GOOD: ECCENTRICITY AND CENTRIPETALITY
}

In Happiness And Contemporary Society : Conference Proceedings Volume (Lviv, March, 20-21, 2021). Lviv: SPOLOM, 2021. P. 40-42. https://doi.org/10.31108/7.2021.6

ISBN 978-966-919-697-2

\section{ЩАСТЯ І БЛАГО: ЕКСЦЕНТРИЧНІСТЬ І ДОЦЕНТРОВІСТЬ}

// Щастя та сучасне суспільство : збірник матеріалів міжнародної наукової конференції (Львів, 20-21 березня 2021 р.). - Львів : СПОЛОМ, 2021. С. 40-42. https://doi.org/10.31108/7.2021.6

ISBN 978-966-919-697-2 


\title{
BOYCHENKO Mykhailo
}

Doctor of Science in Philosophy, Professor, Taras Shevchenko National University of Kyiv (Kyiv, Ukraine)

\section{THE HAPPINESS AND THE GOOD: ECCENTRICITY AND CENTRIPETALITY}

Happiness is always a good for a person: even if a person lacks some other goods, material or spiritual, a person can be happy. We can say that happiness to some extent can compensate for the lack of certain goods. A person is unhappy not when one does not know his center and boundaries, but when one cannot have power over them. Happiness is not rather in the retention of goods, but in the free possession of them. This rule is emphasized by rare exceptions from it: these include a person's dependence on the good of communication with spiritually close ones, relatives, loved ones, friends. Happiness is not a constant escape, but rather a constant learning of happiness. Person uses his / her eccentricity to find his / her new center each time, not to lose it or lose faith in it. Changing one's borders is also not unlimited and completely arbitrary. All this must also be learned, because the loss of goods is also bitter, especially if involuntary or, moreover, against our will, and the loss of some goods is the loss of our very life organic and / or spiritual. Happiness is in the unity of eccentricity and centripetal of some personality: in the constant rejection of the unchanging center and boundaries of one's personality and at the same time in the constant search and new discoveries that partially reaffirm this center and boundaries - but as a result of one's own choice.

Keywords: happiness, goods, eccentricity, centripetality, learning of happiness.

\author{
БОЙЧЕНКО Михайло \\ доктор філософських наук, професор, \\ Київський національний університет імені Тараса Шевченка (Київ Україна)
}

\section{ЩАСТЯ І БЛАГО: ЕКСЦЕНТРИЧНІСТЬ І ДОЦЕНТРОВІСТЬ}

Щастя завжди є благом для людини: навіть якщо ӥй бракує якихось інших благ, матеріальних чи духовних, людина може бути щасливою. Можна сказати, що щастя до певної міри може компенсувати відсутність певних благ, хоча наявність у людини благ не $\epsilon$ перешкодою для щастя, навпаки - володіючи певними благами, людині легше почувати себе щасливою. Однак, нерідко трапляється, що більш багаті на певні блага люди виявляються менш щасливими, аніж більш бідні на ці блага, а подекуди дуже обдаровані благами почувають себе нещасливими, а інколи i зовсім нещасними. В чому ж секрет щастя, якщо брати до уваги його безсумнівний, але неоднозначний зв'язок з благами?

Варто звернутися до класики філософської антропології, зокрема до праць Гельмута Плеснера, який обгрунтовував ексцентричність людської природи: людина сама покладає собі межу з довкіллям, постійно зміщуючи при цьому i межу, і свій власний центр [5]. Таким чином, можна сказати, людина нещаслива не тоді, коли не знає свого центру та меж, а тоді, коли не може мати владу над ними. 
Таким чином, дехто може мати дуже багато благ, його чи їі можуть асоціювати 3 надзвичайно багатим і значущим центром його чи іï особистості, однак, саме таке визнання, саме надмірність благ, як це не виглядає парадоксально, може зв'язувати людину у іiі діях: це трапляється тоді, коли людина не має влади над благами, якими нібито володіє, коли людина не може сама приймати чи відкидати те визнання, яке отримує від оточуючих. Ілюзією $є$ безумовність усіх благ, у тому числі й визнання як безумовного блага.

Якщо ж людина має можливість відмовлятися від певних благ, тоді для щастя це виявляється навіть більш важливим, аніж їх здобуття. Дійсно, не маючи певних благ, можна бути щасливим, якщо ти не вважаєш їх для себе сутнісними, «своїми». Звісно, тут можна згадати і Езопову історію про лисицю і виноград [9], але нехай це і негативний приклад, але він все ж вказує на правильний феномен. Інша справа, що людина не може тривалий час бути щасливою, будучи позбавленою благ. Вона має хоч трохи, але змінювати свій центр, наповнювати його благами, розширювати, хоч у якомусь напрямі, свої межі. Крім того, відсутність деяких життєво важливих благ все ж є суттєвою перешкодою для щастя. Так, може бути навіть щастя приреченого на смерть, але це - миттєве щастя.

Таким чином, щастя не може бути ідентифіковане з якимось іншим благом, аніж саме щастя. Щастя якраз і полягає швидше не в утримуванні благ, але у вільному володінні ними - здатності від них відмовитися і прийняти їх знову. Еріх Фром стверджував, що людині потрібно постійно створювати щось самій, щоби бути вільною і щасливою, саме у цьому полягає для людини модус «буття» натомість прагнення утримати якесь благо у модусі «володіння» швидше приведе людину на шлях деструкції і саморуйнування [7-8]. Щастя є владою над благами, точніше воно потребує такої влади не лише як потенційної, але як актуальної можливості для людини.

Якоюсь мірою тому щастя є запереченням блага, свободою від блага, але не тотальною, нігілістичною, а ігровою, легкою: щастя як благо не заперечує благо як таке, не заперечує володіння благами, а лише заперечує жорстку залежність від благ загалом, а особливо від певних конкретних благ. Механізм пошуків щастя добре передає філософія постмодерну 3 iї принциповою ацентричністю, запереченням жорстких структур, різоматичністю зв'язків, стилізаціями і вільним переходом там, де раніше такий перехід навіть не передбачався - номадизмом $\mathrm{i}$ трансгресією [4].

Втім, щастя не полягає у обов'язковій і постійній втечі від благ. Хоча щастя і нагадує відомого усім невловного «синього птаха» Метерлінка [3] і Сковороди [6], однак кожному птаху теж потрібне своє гніздо. Особливо підкреслюють це правило рідкісні винятки з нього: до таких можна віднести залежність людини від блага спілкування з близькими людьми, рідними, коханою/коханим, друзями. Така залежність $є$ для людини солодкою, адже вона не несе майже ніяких страждань окрім страждання розлуки або хвороби, чи не дай Бог, втрати близької людини. Натомість володіння цим благом робить людину невимовно щасливою. Однак, у цьому винятку також проявляе свою дію встановлене нами правило: ми можемо безмежно урізноманітнювати наше спілкування 3 близькими нам людьми, здійснювати справжню творчість у цій взаємодії. Можемо залучати до цієї 
взаємодії різноманітні блага, які можуть виступати у ролі подарунків рідним, близьким, коханій/коханому. Саме спілкування можна урізноманітнювати різними шляхами, та й зближення 3 близькою людиною не має меж і кінця, його можна здійснювати усе своє життя.

Щастя є не постійною втечею, а швидше постійним навчанням щастю [1-2]. Людина використовує свою ексцентричність для пошуків свого щоразу нового центру, а не для остаточної його втрати або ж втрати віри у нього. Змінювання своїх кордонів теж не $є$ безмежним і абсолютно довільним. Усього цього теж треба навчитися, адже втрата благ також $є$ гіркою, особливо якщо мимовільною або, тим більше, противною нашій волі, а втрата деяких благ $є$ втратою самого нашого життя - органічного або/і духовного. Таким чином, щастя полягає у єдності ексцентричності і доцентровості особистості: у постійній відмові від незмінного центру і меж своєї особистості і водночас у постійному пошуку і нових знахідках, які частково знову підтверджують цей центр і межі - але як результат власного вибору цієї особистості.

\section{ЛІТЕРАТУРА}

1. Бойченко М. (2019) Освітні практики і пошуки щастя (на прикладі шкільної освіти). Щастя та цивілізаційний розвиток : збірник матеріалів міжнародної науково-практичної конференції (Львів, 14-15 листопада 2019 р.). Львів, 41-44.

2. Бойченко М. (2020) Щастя навчання і навчання щастю: ідеали і реалії. Щастя та сучасне суспільство : збірник матеріалів міжнародної наукової конференції (Львів, 20-21 березня 2020 р.). Львів : СПОЛОМ, 36-40.

3. Метерлінк М. (2020) Синій птах / переказ Дз. Федорців. Львів : Апріорі, 128 с.

4. Остапова В. В. (2016) Формы социального ухода в концептах постклассической философии. Актуальні проблеми філософії та соціології. 11, 84-86.

5. Плеснер Х. (2004) Ступени органического и человек: Введение в философскую антропологию / пер. с нем. А.Г.Гаджикурбанова. М.: РОССПЭН, 368 с.

6. Ушкалов Л. (2017) Ловитва невловного птаха: життя Григорія Сковороди. К.: Дух і Літера, 368 с.

7. Фромм Э. (1999) Анатомия человеческой деструктивности / пер. с англ. Э. М. Телятниковой, Т. В. Панфиловой. Мн.: Попурри, 624 с.

8. Фромм Э. (2008) Иметь или быть / пер. с англ. Э. Телятниковой. М.: АСТ: АСТ Москва, 314, [6] с.

9. Эзоп. (2003) Заповеди. Басни. Жизнеописание / пер. с греч. М. Л.Гаспарова. Ростов-на-Дону: Феникс, 288 с.

10. Цицерон Марк Туллий (2000) О пределах блага и зла. Парадоксы стоиков / пер. с лат. Н.А. Федорова; Комментарии Б.М. Никольского; Вступительная статья Н.П. Гринцера. М.: РГГУ, $474 \mathrm{c}$.

11. Эпикур (1955) Письма и фрагменты / пер. с древнегр. В: Материалисты древней Грещиии. М.: Политиздат. С. 179-236. 